\title{
PULMONARY EDEMA DUE TO MITRAL STENOSIS IN PREGNANCY: A CASE REPORT
}

\author{
Handan GULEC ${ }^{1}$,Suleyman AKARSU ${ }^{2}$, Semih DEGERLI $^{1}$, Fatma BERCIN ${ }^{1}$, Necla DERELI ${ }^{1}$, Saziye SAHIN $^{1}$ \\ ${ }^{1}$ Department of Anesthesiology and Intensive Care, Kecioren Training and Research Hospital, Ankara, Turkey \\ ${ }^{1}$ Department of Obstetrics and Gynecology, Kecioren Training and Research Hospital, Istanbul, Turkey
}

\begin{abstract}
SUMMARY
Mitral stenosis is a valve disease, that creates the most trouble during pregnancy and birth process. Plasma volume increases due to sodium and water retention during pregnancy and the second trimester of pregnancy it reaches the maximum level. At the first trimester of pregnancy, normal cardiac output increases by 30 to $40 \%$ and this condition causes significant hemodynamic changes in patients with mitral stenosis. Pulmonary edema occurs rapidly with high left atrial pressure due to increase of preload. It is noted that acute pulmonary edema is the primary cause on maternal mortality in pregnant women with mitral stenosis. Clinical signs are becoming evident, especially after the 12th week. Despite the best conservative treatment, maternal and infant mortality can be seen.In this case, we present a rare occurrence of pulmonary edema following dispne due to mitral stenosis in a 19 years old pregnant at 29th week of the first pregnancy.
\end{abstract}

Key words: mitral stenosis, pregnancy, pulmonary edema

Journal of Turkish Society of Obstetrics and Gynecology, (J Turk Soc Obstet Gynecol), 2012; Vol: 9 Issue: 1 Pages: 70- 2

\section{GEBELIKTE MITRAL STENOZA BAĞLI GELIȘEN AKCİĞER ÖDEMİ: OLGU SUNUMU}

\section{ÖZET}

Mitral darlık, gebelik ve doğum sürecinde en çok sıkıntı yaratan kalp kapak hastalığldır. Gebelik süresince artan sodyum ve su tutulmasına bağll olarak plazma volümü artmakta, gebeliğin ikinci trimesterinde en yüksek düzeye ulaşmaktadır. Dolayısıyla gebeliğin ilk trimesterinde kardiak output normalin \%30-40’ kadar artmakta, mitral stenozlu hastalarda ise bu durum önemli hemodinamik değişikliklere neden olmaktadır. Preload artışı ile sol atrial basınç artmakta, artan pulmoner venöz konjesyon sonucu da kolaylıkla akciğer ödemi ortaya çıkmaktadır. Mitral stenozlu gebelerde anne ölümlerinin başlıca nedeninin akut akciğer ödemi olduğu belirtilmektedir. Klinik bulgular özellikle onikinci haftadan sonra belirgin hale gelmekte, en iyi ve ileri konservatif tedavilere rağmen anne ve bebek ölümleri görülebilmektedir. Burada 19 yaşında ilk gebeliği olan, gebeliğinin 29. haftasında kasılma şikayeti ile kliniğimize başvuran ve hastanede izlemi sırasında gelişen solunum yetmezliği üzerine yapılan incelemede mitral stenoz ve buna bağll akciğer ödemi tespit edilen olgu sunulmaktadır.

Anahtar kelimeler: akciğer ödemi, gebelik, mitral stenoz

Türk Jinekoloji ve Obstetrik Derneği Dergisi, (J Turk Soc Obstet Gynecol), 2012; Cilt: 9 Sayl: 1 Sayfa: 70- 2

Address for Correspondence: Süleyman Akarsu. Keçiören Ankara.

Phone.: + 90 (532) 3242025

e-mail:suleymanakarsu@hotmail.com

Received: 24 September 2010, revised: 10 December 2010, accepted: 18 January 2011, online publication: 08 December 2011 


\section{INTRODUCTION}

Pregnancy, some kind of physiological changes due to a troublesome process, even in healthy women. Especially water and sodium uptake is negatively affects to respiration and circulation ${ }^{(1)}$.

Beta-hemolytic streptococcal infection, and then western countries in the developing cardiac complications eradicated, in developing countries where we also cover such as heart disease usually presents with may ${ }^{(2)}$. The mitral valve is usually 4$6 \mathrm{~cm}^{2} 2-2.2 \mathrm{~cm}^{2}$ valve area falls below the clinically finding does not ${ }^{(3)}$. Narrowing mitral valve area as a result of increased left atrial pressure, pulmonary venous as pressure rises, and finally chronic pulmonary capillary pressure and pulmonary artery pressure increased by interstitial pulmonary edema and alveolar wall, with the conclusion in the thickening of the pulmonary hypertension is caused. At the end of ventilation perfusion disturbing relationship ${ }^{(3)}$. Cardiac problems in pregnancy is observed, a ratio of $1-3 \%$ and maternal mortality by $10 \%$ - 15 depends upon the cause ${ }^{(1)}$. Rheumatic heart disease the most common causes of heart valve disease $^{(4)}$. The most common valvuler heart disease is mitral stenosis ${ }^{(5)}$.

In this case study will be covered in a pregnancy complicated with pre-existing cardiac valve disease in unknown.

\section{CASE REPORT}

Nineteen years old patient with the first pregnancy, in 29th pregnancy week the woman was admitted to the Obstetrics Clinic because of contraction-like pains. During this period, patients had a complaint of shortness of breath. Patient complaints of gradually increasing over the past week, daily life has begun restrictions expressed. because of physical examination identified tachycardia (pulse: 140/min), tachypnea (respiratory rate: $40 / \mathrm{min}$ ) internal medicine were consulted. In internal examination, crepitant rales and rhonchi were osculted, that's why the patient was consulted chest diseases clinic. In the physical examination of Chest Diseases Clinic was osculted middle and lower zones rales, dyspnea, and agitation circumstances the patient was recommended to follow-up intensive care unit.
After the Anesthesiology Clinic evaluation the patient was admitted to intensive care unit.

In the first examination of the patient was found; fever: $36.9^{\circ} \mathrm{C}$, pulse $82 / \mathrm{min}$, Blood pressure: $110 / 80 \mathrm{mmHg}$, $\mathrm{O} 2$ saturation on room air: $80 \%$, arterial blood gases pO2:50.6, pCO2: 23.8. The patient had cooperation difficulties because of agitation and respiratory failure due to a shortage of oxygen. Apical diastolic murmur was heard at auscultation. She hadn't evidence of peripheral or central cyanosis. Bilateral pretibial $(+++)$ pitting edema was detected. In the patient's ECG, sinus tachycardia, common voltage drop and rare extra ventricular beats were found.

Taking the necessary protective measures in the abdominal region in the chest $\mathrm{x}$-ray was seen increasing of cardiothoracic index and pulmonary conus. The patients had to be treated with acute pulmonary edema according to the findings of the current examination and laboratory diagnosis. Supporting of $100 \%$ oxygen by mask (4lt/dak) was started to the patient. The infusion of furosemide for edema and opioid (remifentanil $0.1 \mathrm{mcg} / \mathrm{kg} / \mathrm{min}$ ) infusion for respiratory difficulties were started. Hourly urine output was followed via attachment of urofix. The patient was consulted by the Cardiology doctor; In the ECHO mitral valve stenosis was detected. There were calculated to Mitral Valve Area: $1.1 \mathrm{~cm}^{2}$ and Pulmonary Arterial Pressure: 60 mmHg. Verapamil was added to treatment with the proposal of Cardiology Clinic. It was recommended to transfer for patient's advanced cardiac treatment (balloon valvuloplasty) after the acute phase. Thanks to oxygenation and adequate diuresis, edema was resolved within 24 hours and the patient was transferred by ambulance the supervision of a doctor when patient's general condition was suitable to transfer.

According to information about the patient; her valvuloplasty was performed successfully, provided continuity of the pregnancy, at the 39th weeks of gestation by cesarean section baby was born 3250 gram and 7-9 APGAR scores. It was learned that complications weren't related to the mother and baby.

\section{DISCUSSION}

Mitral stenosis, valve disease of pregnancy and birth process that creates the most distress. During pregnancy 
due to increased sodium and water retention, plasma volume increases, the maximal level reaches the second trimester of pregnancy. However, depending on cardiac output increase up to $30-40 \%$ of normal during the first trimester of pregnancy, the situation in patients with mitral stenosis is causing significant hemodynamic changes ${ }^{(3,6)}$. Increase of Preload and left atrial pressure increases, as a result of increased pulmonary venous congestion or pulmonary edema occur easily.

Clinical findings becomes apparent, especially after the $12^{\text {th }}$ week, the best and advanced maternal and infant mortality can be seen in spite of conservative treatment ${ }^{(3)}$. The major cause of maternal mortality in pregnant women with mitral stenosis reported that acute pulmonary edema(7). It is possible that near normal grosses with taking the necessary precautions if the patient knows that the cases of mitral stenosis itself. However, as in our patient, who don't know rheumatic fever and valve disease, serious cardiac problems is happen during pregnancy.

In such a case, the most important points concerning anesthesia, the patient's emergency clinic in the control of cardiac and respiratory difficulties, and required commissurotomy up process is applied to the provision of life support; also required it appropriate anesthesia for emergency planning of birth(8-10).

\section{REFERENCES}

1. Arafeh JM, Baird SM. Cardiac disease in pregnancy.Crit Care Nurs Q.2006; Jan-Mar; 29(1):32- 52.

2. Ali Kolusarı, Şahin Zeteroğlu, Hanım Güler Şahin, Mansur Kamacı. Gebelik ve kalp hastalığı: Altmışyedi olgunun değerlendirilmesi. Perinataloji Dergisi. 2008; 16819: 14- 8 .

3. Burwell CS, Metcalfe J: Heart disease and pregnany. Physilogy and management. Little Brown, Boston. 1968; p:127.

4. Nqayana T, Moodley J, Naidoo DP. Cardiac disease in pregnancy. Cardiovasc J Afr. 2008; May-Jun; 19(3): 145- 51.

5. Atilla Kayıhan, Hakkı Aydoğan, Şenol Yavuz, İzzet Arkan, Ergin Eren. Gebelik ve mitral stenozu. GKD Cer. Derg. 1991; 1. $27-30$.

6. Szekely P Turner R Sheith I: Pregnancy and the changing pattern of rheumatic heart disease Br. Heart J 1973; 35: 1293.

7. Criteria Commite of the New York Heart Association. Disease of the heart and blood vessels. Nomenclature and criteria for diagnosis. 6th. Ed. Little Brown: Boston. 1964; p:112.

8. Hasan Fehmi Töre, Hürkan Kurşaklığlu, Atila İyisoy, Cem Barçın, Basri Amasyalı, Ertan Demirtaş. Gebe bir kadında balon mitral valvuloplasti uygulaması. (olgu sunumu). Gülhane Tip Dergisi. 2003; 45(2): 201- 2.

9. Soner Yavaş, H. Zafer İşcan, Levent Mavioğlu, Utku Ünal, Ahmet Akgül, Cemal Levent Birincioğlu. Mitral darlık ve gebelik birlikteliğinde kapalı komissürotominin yeri: Uzun dönem sonuçları. Türkiye Klinikleri J Cardivascular Sci 2007; 19: $105-110$.

10. Pieper PG, Balci A, Van Dijk AP. Pregnancy in women with prosthetic heart valves. Neth Heart J. 2008; Dec; 16(12): 406- 11. 